\title{
Penyuluhan Literasi Baca Tulis Pada Siswa SMA
}

\author{
Maria Cleopatra, Sara Sahrazad, Aster Pujaning Ati, Loecita Sandiar, \\ Toto Widiarto, Sigit Widiyarto* \\ Universitas Indraprasta PGRI \\ email: sigit.widiyanto@gmail.com
}

\begin{abstract}
Students' reading interest is still low. This is due to a lack of habituation and examples from parents and teachers. Students need to be given a good example. The purpose of this activity is to increase the interest in reading books of SMA Alikhlas Bekasi students. Community service activities are held at SMA Alikhlas Bekasi. The number who participated in this activity was 15 students. The method of activity is carried out by means of needs analysis, this technique is an intensive interaction stage between the system analyst and the community of system users (end users), where the system development team shows its expertise to get user responses and trust, so that it gets good participation, besides providing assistance, evaluation, and determining needs and habituation. The results of the activity showed that the increase in the number of books read was $0.8 \%$ and the high school students were able to carry out the plans and applications of written literacy well.
\end{abstract}

Keywords: counseling, literacy, reading, writing

\begin{abstract}
Abstrak
Minat baca siswa masih rendah. Hal ini disebabkan kurangnya pembiasaan dan contoh dari para orang tua dan guru. Siswa perlu diberikan contoh yang baik.Tujuan kegiatan ini adalah untuk meningkatkan minat baca buku siswa SMA Alikhlas Bekasi .Kegiatan pengabdian masyarakat diadakan di SMA Alikhlas Bekasi. Jumlah yang ikut dalam kegiatan ini sebanyak 15 siswa. Metode kegiatan dilakukan dengan cara pengumpulan analisis kebutuhan,teknik ini merupakan tahap interaksi intensif antara analis sistem dengan komunitas pemakai sistem (end-user), dimana team pengembangan sistem menunjukkan keahliannya untuk mendapatkan tanggapan dan kepercayaan pemakai, sehingga mendapat partisipasi yang baik selain itu dilakukan pendampingan,evaluasi,dan penentuan kebutuhan dan pembiasaan. Hasil kegiatan menunjukkan bahwa ada kenaikan jumlah buku yang telah dibaca, sebesar $0.8 \%$ dan para siswa SMA sudah mampu melaksanakan rencana dan aplikasi dari literasi baca tulis dengan baik.
\end{abstract}

Kata Kunci: Penyuluhan, Literasi ,Baca, tulis

\section{PENDAHULUAN}

Penguasaan baca-tulis, siswa mampu mengatur kualitas hidup, terutama dalam zaman yang lebih canggih. Ketatnya persaingan hidup dan perubahan yang serba cepat, membuat pembekalan ilmu menjadi sangat penting. Hal itu patut disadari oleh para siswa dan orang tua, sebab dengan membekali ilmu, mereka harus mampu menguasai literasi baca tulis.
Penyerapan ilmu akan lebih cepat dan belajar mandiri. Para siswa yang tidak mampu menguasai literasi baca tulis dengan baik, maka ia akan mengalami masalah, contohnya semisal seseorang baru saja membeli sebuah gawai ( handphone), namun ia tidak mampu memahami dan membaca dengan cermat petunjuk pemakaian, maka gawai tersebut akan lebih mudah rusak. 
Dapat dikatakan bahwa membaca merupakan kunci guna mempelajari berbagai ilmu pengetahuan, termasuk informasi dalam kehidupan. Pada tahap selanjutnya setelah membaca teks, membaca pemahaman merupakan tahap yang perlu diperhatikan salah satu hal yang penting dalam segala macam proses pembelajaran ( AN.Mulanjani dan CW Anggraeni:2019). Pada tahap ini para siswa mampu membayangkan apa yang sedang dibaca dan dapat mengasah diri untuk berempati dengan situasi luar yang dipaparkan dalam teks .

Pemahaman membaca juga erat dengan minat baca dan tulis. Dengan memahami dan menguasai kosa kata di dalam teks, maka para siswa akan mendapat pengetahuan baru, timbul rasa keingintahuan para siswa , sehingga dapat mengasah otak dan berpikir kritisnya.

Membaca akan menambah wawasan dan membuka lebih banyak pilihan-pilihan yang tepat dalam hidup. Berkaitan erat dengan membaca, kemampuan menulis pun penting untuk dimiliki dan dikembangkan. Membaca dan menulis berkorelasi positif dengan kemampuan berbahasa dan penguasaan kosa-kata. Masukan kata-kata dan gagasan didapat melalui membaca, sedangkan keluarannya disalurkan melalui tulisan.

Siswa yang yang membiasakan membaca dan menulis bisa menemukan kata atau istilah yang tepat untuk mengungkapkan suatu hal.Untuk dapat menyerap informasi dari bacaan atau meramu ide menjadi tulisan diperlukan fokus yang baik. Dengan begitu, membiasakan diri untuk melakukan aktivitas membaca dan menulis akan meningkatkan daya konsentrasi. Kinerja otak menjadi lebih maksimal. Di samping itu, imajinasi dan kreativitas pun akan tumbuh karena semakin banyak wawasan yang didapat dan semakin tajam cara berpikir yang terbentuk. Membaca dan menulis juga bisa dijadikan sarana hiburan yang dapat menurunkan tingkat
stres.Namun kemampuan siswa masih lemah dalam pembelajaran membaca, hal ini disebabkan modal utama dalam pembelajaran di negara ini adalah anak harus mampu membaca ( $\mathrm{S}$. Rohman:2017), Pada penelitian lain dikatakan bahwa Budaya membaca dan menulis dikalangan siswa masih rendah, perlu adanya upaya sungguh-sungguh dari berbagai kalangan (Ati, A. P., \& Widiyarto, S, 2020)

Kemampuan dan jenjang hidup dapat menjadi lebih baik dengan adanya pembiasaan dan kemampuan baca-tulis. Dengan tidak adanya literasi baca-tulis yang baik, kehidupan akan lebih sempit dan terbatas, bahkan berhadapan dengan banyak kendala. Oleh karena itu, literasi baca-tulis perlu dikenalkan, ditanamkan, dan dibiasakan kepada masyarakat Indonesia, khususnya oleh para siswa, guru, orang tu dan masyarakat luas.

\section{METODE PENGABDIAN}

Adapun tahapan kegiatan yang dilakukan adalah Langkah-langkah yang akan dilakukan adalah sebagai berikut:

1. Pengumpulan analisis kebutuhan. teknik ini merupakan tahap interaksi intensif antara analis sistem dengan komunitas pemakai sistem (end-user), dimana team pengembangan sistem menunjukkan keahliannya untuk mendapatkan tanggapan dan kepercayaan pemakai, sehingga mendapat partisipasi yang baikKegiatan ini dilakukan secara daring, dengan memberikan pertanyann kepada para mitra dilakukan dengan cara wawancara dengan para guru,siswa dan beberapa orang-tua. Hal ini dilakukan agar mendapat gambaran dan data awal untuk langkah selanjutnya

2. Pendampingan, setelah mendapat data awal, tim mendapat gambaran singkat akan kebutuhan atau kemampuan sekolah dan para siswa untuk melakukan literasi baca tulis ini. Sejumlah kendala sudah dapat 
diidentifikasi dengan baik, sehingga para guru siswa tidak merasa malu.

3. Evaluasi, setelah memberikan beberapa arahan dan penyuluhan kepada para siswa, maka tim mengecek dan memberikan pertanyaan ,apa saja item yang sudah dilaksanakan atau belum tercapai.

4. Penentuan kebutuhan dan pembiasaan. Langkah ini dilakukan dengan membiasakan kegiatan secara rutin . Pembiasaan ini dilakukan berdasarkan penentuan kebutuhan para siswa. Kebutuhan tentunya dijelaskan pada tahap sebelumnya, dengan cara penyuluhan dan contoh nyata dari para tim. Secara garis besar metode pelaksanaan mengikuti alur / denah di bawah ini :

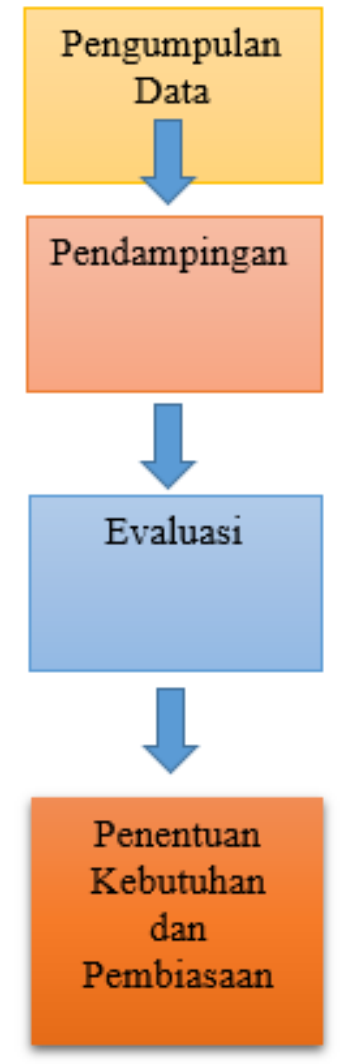

Gambar 1. Alur Metode Pelaksanaan
Perencanaan penyusunan produk luaran dengan menyesuaikan solusi yang sesuai dengan kebutuhan mitra

\section{HASIL DAN PEMBAHASAN}

Mitra dalam usulan Program Kemitraan Masyarakat (PKM) ini adalah Panti Asuhan Darul Ilmi yang beralamat di jalan Rawasari I, Kelurahan Tangkerang Tengah, Pekanbaru. Panti asuhan baru berdiri tahun 2018 dan dikelola oleh seorang ibu asuh dengan empat orang yang membantu secara aktif dalam pengelolaannya. Beberapa orang yang berperan aktif tersebut adalah bendahara, sekretaris, dan penanggung jawab rumah tangga.

Panti asuhan telah mengasuh 27 orang anak dengan tingkat pendidikan yang bervariasi seperti yang tercantum pada Tabel 1. Terdapat 69,23 persen (9 orang) anak yang belum lancar membaca dari total keseluruhan anak dengan tingkat pendidikan sekolah dasar dan 44,44\% (12 orang) anak dari total keseluruhan yang sudah lancar membaca namun memiliki minat baca yang rendah. Hal ini menandakan bahwa diperlukan strategistrategi yang harus dilakukan untuk meningkatkan minat baca anak di panti asuhan.

Pada Program PKM ini dilakukan penyerahan bantuan berupa donasi buku bacaan layak baca, rak buku 4 tingkat, masker untuk anak-anak panti, dan sabun cuci tangan. Jumlah donasi buku layak baca yang diterima adalah sejumlah 56 buku sedangkan jumlah dana dan donasi yang terkumpul hingga tanggal 19 Desember 2020 adalah sejumlah Rp1.143.500,00 (satu juta seratus empat puluh tiga ribu lima ratus rupiah).

Tabel 1 Data anak di Panti Asuhan Darul Ilmi Berdasarkan Hasil Wawancara dengan Pengelola Panti Tahun 2019

\begin{tabular}{cccc}
\hline Tingkat pendidikan & Kelas & Jumlah Anak & Keterangan \\
\hline Belum sekolah $(<5$ tahun $)$ & - & 6 & Belum lancar membaca \\
\hline
\end{tabular}




\begin{tabular}{llll}
\hline & 1 & 2 & Belum lancar membaca \\
\multirow{2}{*}{ Sekolah Dasar } & 2 & 1 & Belum lancar membaca \\
& 3 & 3 & Belum lancar membaca \\
& 4 & 3 & Belum lancar membaca \\
& 5 & 3 & Sudah lancar membaca minat baca rendah \\
Sekolah Menengah & 6 & 1 & Sudah lancar membaca minat baca rendah \\
Pertama (SMP) & 1 & 2 & Sudah lancar membaca minat baca rendah \\
& 2 & 3 & Sudah lancar membaca minat baca rendah \\
Sekolah Menengah Atas & 3 & 0 & Sudah lancar membaca minat baca rendah \\
(SMA) & 1 & 0 & Sudah lancar membaca minat baca rendah \\
& 2 & 1 & Sudah lancar membaca minat baca rendah \\
& 3 & 2 & Sudah lancar membaca minat baca rendah \\
\hline
\end{tabular}

Seluruh dana yang terkumpul telah digunakan untuk belanja buku donasi yang telah diserahkan pada tanggal 25 Desember 2020. Penyerahan bantuan dan donasi dilakukan dengan menyertakan penandatanganan Berita Acara sebagai tanda bukti serah terima dan pelaksanaan pengabdian kepada Masyarakat di Panti Asuhan seperti pada gambar dibawah ini.

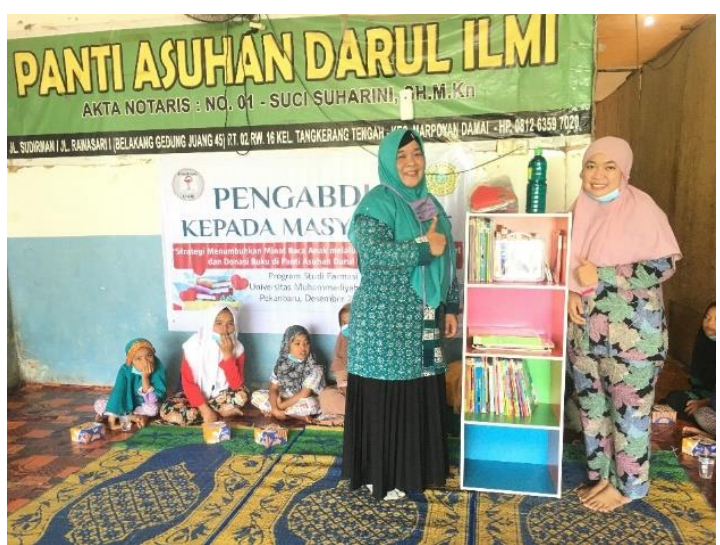

Gambar 1 Serah terima donasi

Buku donasi yang diserahkan terdiri dari buku-buku cerita anak, buku pengetahuan islami, buku belajar menghitung, buku belajar mewarnai, dan disertai dengan pensil warna untuk mendukung aktivitas anak-anak untuk mewarnai bagi yang belum bisa membaca. Setelah penyerahan buku donasi terlihat bahwa anak-anak panti asuhan sangat semangat untuk membaca buku yang terlihat pada Gambar 2. Semoga bukubuku donasi ini dapat meningkatkan minat baca anak-anak di Panti Asuhan Darul Ilmi Pekanbaru. Ketersediaan koleksi buku bacaan yang sesuai dengan usia anak-anak terbukti dapat menumbuhkan rasa ingin tahu dan keinginan anak-anak panti untuk membaca maupun menggunakan buku tersebut [9], [10].

Pelaksanaan penyuluhan obat untuk anak-anak di panti asuhan dan workshop kartu kuartet dilaksanakan pada hari yang sama dengan serah terima donasi buku. Jumlah panitia pelaksana adalah 10 orang yang terdiri dari 3 orang dosen dan 7 orang mahasiswa farmasi perwakilan dari HIMAFARM UMRI. Jumlah anak-anak panti asuhan yang hadir pada pelaksanaan kegiatan dan telah mengisi daftar hadir adalah sejumlah 25 orang. Kegiatan penyuluhan obat disampaikan oleh Ibu apt. Dewi Gulyla Hari, M.S.Farm. Materi yang disampaikan pada penyuluhan obat adalah pengenalan tentang obat, penjelasan tentang cara pakai obat, dan penyuluhan tentang anti penyalahgunaan obat. Penyuluhan ini (Gambar 3) bertujuan untuk mengedukasi anak-anak panti dalam menggunakan maupun memilih obat. 

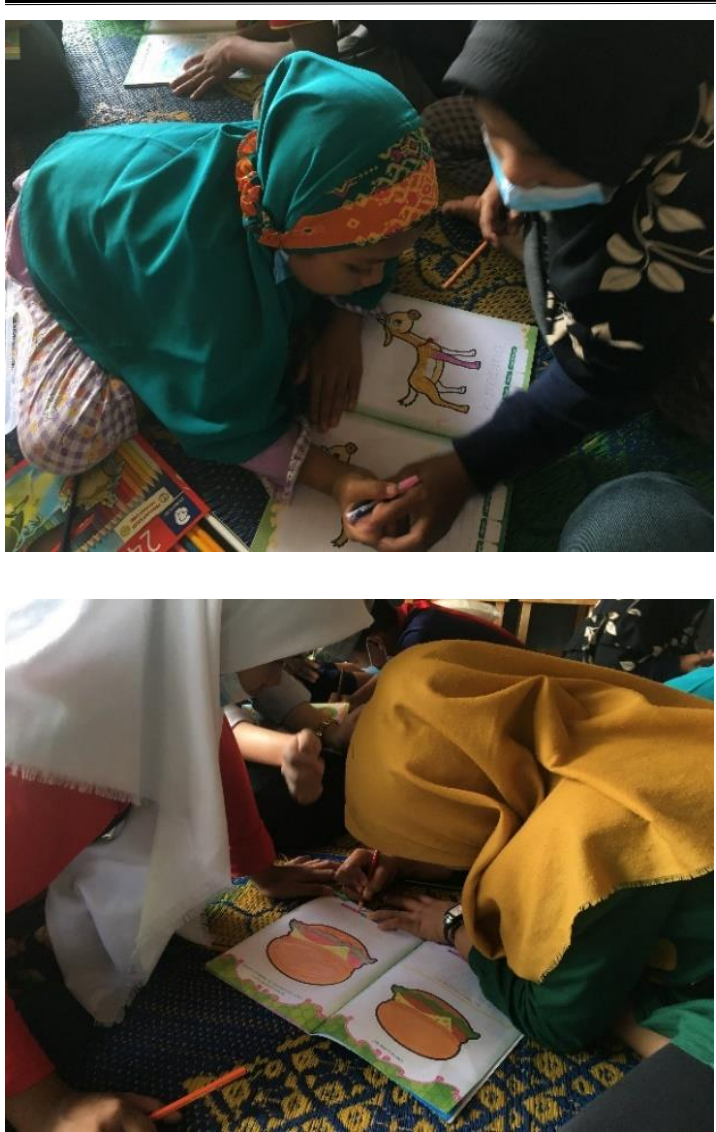

Gambar 2 Keseruan anak panti belajar sambil bermain

Workshop kartu kuartet penyalahgunaan obat (Gambar 4) dilakukan terhadap 11 orang anak-anak panti yang bisa membaca. Bagi anak-anak panti yang masih kecil atau belum bisa membaca dibimbing untuk melakukan kegiatan belajar mengenal benda-benda dan mewarnai. Workshop disertai dengan pencarian pemenang dari masing-masing grup dan pemberian hadiah.

Evaluasi pengetahuan anak-anak panti setelah kegiatan penyuluhan dan workshop kartu kuartet dilakukan dengan menyebarkan kuesioner sebelum dan setelah pelaksanaan kegiatan.

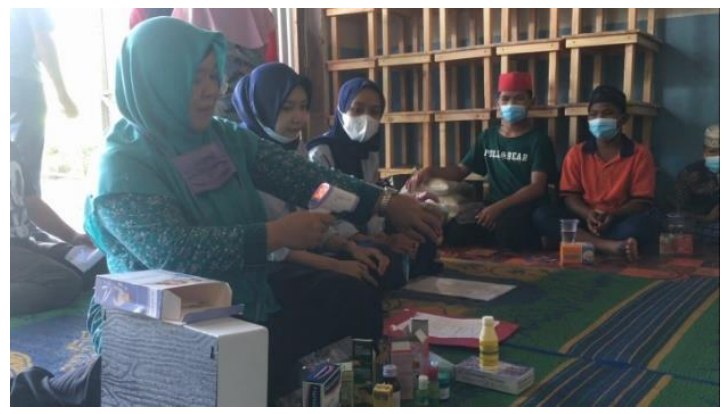

Gambar 3 Penyuluhan Obat
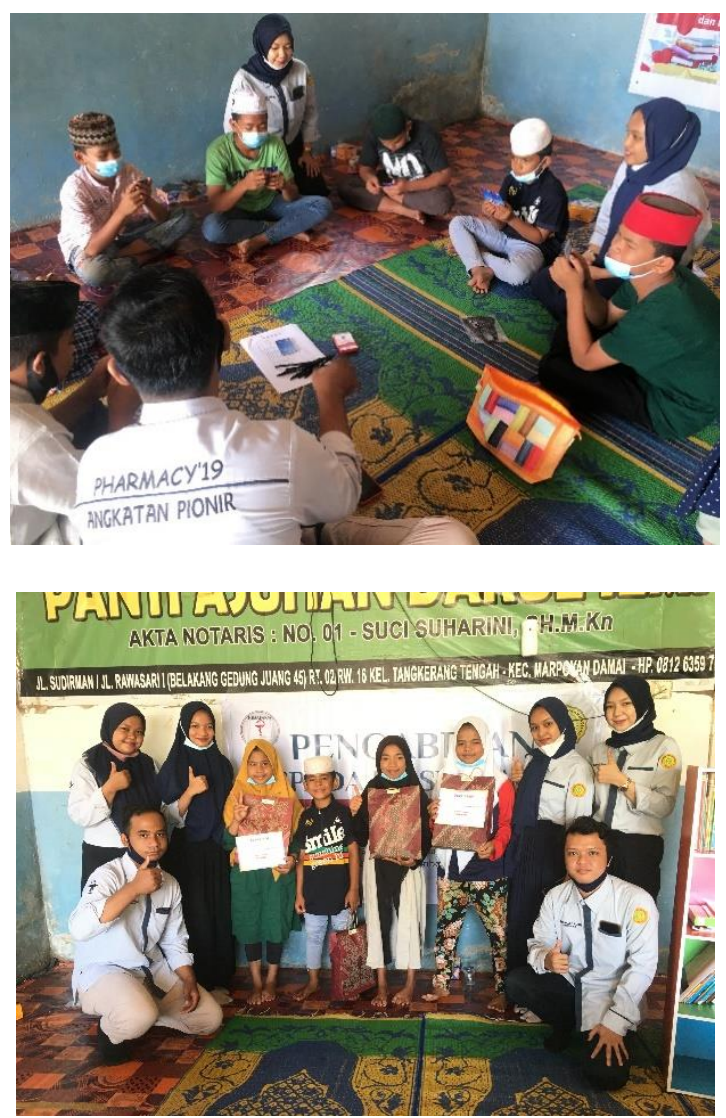

Gambar 4 Pelaksanaan workshop kartu kuartet

Berdasarkan hasil evaluasi yang tercantum pada Tabel 2 diperoleh bahwa terdapat peningkatan skor rata-rata antara sebelum dan setelah pelaksanaan penyuluhan obat dan workshop kartu kuartet. Hasil evaluasi ini mendukung penelitian sebelumnya yaitu penggunaan kartu kuartet memiliki pengaruh terhadap pengetahuan siswa sekolah dasar tentang penyalahgunaan obat. 
Tabel 2 Hasil evaluasi menggunakan kuesioer

\begin{tabular}{llcc}
\hline \multirow{2}{*}{ No. } & \multicolumn{1}{c}{ Nama } & \multicolumn{2}{c}{ Skor } \\
\cline { 3 - 4 } & & Sebelum & Sesudah \\
\hline 1 & Ezi Saputra & 90 & 100 \\
\hline 2 & Ilma & 90 & 100 \\
\hline 3 & Indra & 80 & 80 \\
\hline 4 & Lisa & 90 & 100 \\
\hline 5 & M. Ridoan & 80 & 90 \\
\hline 6 & Mhd. Ripai & 70 & 90 \\
\hline 7 & Mhd. Romadon & 50 & 100 \\
\hline 8 & M. Ismail & 90 & 100 \\
\hline 9 & Rindu & 90 & 100 \\
\hline 10 & Umar Soleh & 100 & 100 \\
\hline 11 & Zai Fina Sahida & 90 & 100 \\
\hline & Rata-rata skor & 83.64 & 96.36 \\
\hline
\end{tabular}

\section{SIMPULAN}

Kegiatan Program Pengabdian kepada Masyarakat ini terdiri dari donasi buku bacaan, penyuluhan obat, workshop kartu kuartet, dan evaluasi. Workshop kartu kuartet dilakukan terhadap 11 orang anakanak panti yang bisa membaca dan selebihnya diarahkan untuk belajar sambil bermain serta melakukan aktivitas mewarnai. Kegiatan PKM ini berjalan dengan lancar dan anak-anak panti terlihat sangat antusias dalam mengikuti kegiatan. Anak-anak panti asuhan terlihat bersemangat untuk membaca buku donasi dan menggunakan buku-buku untuk mewarnai. Kegiatan PKM ini juga dapat meningkatkan pengetahuan anak-anak panti tentang obat-obatan secara umum dan antipenyalahgunaan obat.

\section{UCAPAN TERIMAKASIH}

Ucapan terima kasih diberikan kepada Lembaga Penelitian dan Pengabdian kepada Masyarakat (LPPM) Universitas Muhammadiyah Riau atas pendanaan yang diberikan sehingga pengabdian ini dapat terlaksana dengan baik.

\section{DAFTAR PUSTAKA}

[1] Badan Pusat Statistik, Statistik Pemuda Indonesia 2015. Jakarta: Badan Pusat Statistik, 2015.

[2] I. N. Triatma, "Minat baca pada siswa kelas Vi Sekolah Dasar Negeri Delegan 2 Prambanan Sleman Yogyakarta," E-Jurnal Skripsi Progr. Stud. Teknol. Pendidik., vol. 5, no. 6, p. 167, 2016.

[3] E. Saepudin, "Tingkat Budaya Membaca Masyarakat," J. Kaji. Inf. Perpust., vol. 3, no. 2, pp. 271-282, 2015.

[4] N. U. Millah, "Meningkatkan minat baca." [Online]. Available: http://www.bpkp.go.id/pustakabpk p/index.php? $\mathrm{p}=$ tingkat minat baca. [Accessed: 06-Sep-2019].

[5] Karsono, Y. Sujana, J. Daryanto, and N. Yustinus, "Pada Siswa Sekolah Dasar," Mimb. Sekol. Dasar, vol. 1, no. April, pp. 43-49, 2014.

[6] R. I. Habiba, "Peningkatan Hasil Belajar Dengan Media Kartu Kwartet Dalam Keterampilan Menyusun Portofolio," Ilmu Pendidik. J. Kaji. Teor. dan Prakt. Kependidikan, vol. 2, no. 1, pp. 8591, 2017, doi: 10.17977/um027v2i12017p085.

[7] A. E. Hartanto, Sukarno, and Kuswadi, "Kartu kata bergambar pada anak kelompok B Tk Negeri pembina Surakarta tahun pelajaran 2013/2014," J. FKIP UNS, vol. 2, no. $1,2014$.

[8] Hannan, P. Wikaningtyas, and I. K. Adnyana, "Edukasi Anti Penyalahgunaan Obat Kepada Siswa SD Di Kota Palu Melalui Media Kartu Kuartet," J. Farm. Galen. (Galenika J. Pharmacy), vol. 5, no. 1, pp. 20-25, 2019, doi: 10.22487/j24428744.2019.v5.i1.11 933.

[9] O. : Periyeti, "Usaha Meningkatkan 
Minat Baca Mahasiswa," J. Pustaka Budaya, vol. 4, no. 1, p. 126837 , 2017.

[10] K. Suharmono, "Upaya Meningkatkan Minat Baca sebagai Sarana untuk Mencerdaskan Bangsa," J. Pena Indones., vol. 1, no. 1, pp. 79-95, 2015. 